\title{
Coulisses
}

Revue de théâtre

13 | Hiver 1996

Varia

\section{Mirad, un garçon de Bosnie d'Al de Bont}

Mise en scène de René Loyon

\section{Madeleine Laude}

\section{(2) OpenEdition}

\section{Journals}

Édition électronique

URL : http://journals.openedition.org/coulisses/4321

DOI : $10.4000 /$ coulisses.4321

ISSN : 2546-9460

Éditeur

Presses universitaires de Franche-Comté

\section{Édition imprimée}

Date de publication : 1 janvier 1996

Pagination : 73-74

ISSN : $1150-594 \mathrm{X}$

\section{Référence électronique}

Madeleine Laude, « Mirad, un garçon de Bosnie d'Al de Bont », Coulisses [En ligne], 13 | Hiver 1996, mis en ligne le 15 mars 2019, consulté le 08 octobre 2020. URL : http://journals.openedition.org/coulisses/ 4321 ; DOI : https://doi.org/10.4000/coulisses.4321

Ce document a été généré automatiquement le 8 octobre 2020.

Coulisses 


\title{
Mirad, un garçon de Bosnie d'Al de Bont
}

\author{
Mise en scène de René Loyon
}

Madeleine Laude

Désirant poursuivre l'expérience des " petites formes ", René Loyon, et avec lui tout le C.D.N., a choisi de monter Mirad, un garçon de Bosnie, une pièce du dramaturge hollandais Al De Bont. Pièce courte à deux personnages, elle a été jouée une vingtaine de fois hors des murs du théâtre ${ }^{1}$. Les recettes de la tournée seront intégralement versées à une école de Sarajevo par l'intermédiaire du Collectif Solidarité-Bosnie de Besançon.

Djuka et Fazila, oncle et tante de Mirad, réfugiés en France, s'adressent directement aux spectateurs. Leur premier mot est «Pardon ». Vont-ils nous demander l'heure ou un renseignement? Alors nous pourrions répondre vite et penser à autre chose... Non, ils s'excusent d'être là, chez nous. Et s'ils nous demandent pardon, c'est qu'ils vont prendre un peu de notre temps pour nous raconter leur histoire.

Ce n'est pas facile, ils se sentent si « laids », si « différents » et leur histoire est « assez sinistre ». Mais sans que nous sachions ce qui les pousse, ils ont décidé de faire devant nous cette sorte de bilan.

Leur histoire s'étend sur une année, d'avril 1992 - début de la guerre en Bosnie - à avril 1993. Le récit évoque tout ce que nous savions déjà sur le drame bosniaque: les bombardements, les massacres et les viols des civils, les tortures dans les camps de prisonniers, le siège de Sarajevo... Mais cette fois-ci, nous sommes à l'intérieur de la tourmente, aux côtés de Mirad et de sa famille. L'image d'une foule anonyme de victimes impuissantes, si souvent montrée par les médias, disparaît. Elle laisse la place à des personnes singulières qui dans leur effort pour comprendre, résister, aimer, conservent et manifestent leur dignité d'êtres humains.

Mirad, ce garçon qui fête ses treize ans le 7 avril 1992, nous ne le verrons pas. Il est la figure errante des réfugiés, ces « gens emportés par le vent comme des feuilles mortes par le monde entier. " Comme tant d'autres Bosniaques, sa famille réunit toutes les communautés : son père et son oncle Djuka sont musulmans, Fazila est croate et la mère de Mirad est serbe. Avant, ces distinctions n'avaient pas de sens, pas de réalité 
dans leur être. Mais le virus de la haine et la guerre en ont fait le prétexte à d'épouvantables tueries.

Quand il comprend que sa famille est mixte, Mirad confie à son journal intime: «J'aurais mieux fait de ne pas me réveiller.» La tragédie se situe là : quoi qu'il fasse, il est «devenu » un musulman et il va apprendre ce que cela signifie. Sa petite sœur et son père meurent sous ses yeux, sa mère est emmenée par des milices serbes dans un camp de viols. Lui-même séjournera dans un camp de prisonniers avant d'être libéré et envoyé à Rennes. Mais son errance ne s'arrête pas là. Si sa mère a été libérée, elle a besoin de lui. Accomplissant pour la première fois de sa vie un acte libre, il s'enfuit pour la Bosnie.

2 La trame principale est constituée par le récit que Fazila et Djuka adressent directement au public. Mais au détour d'un mot ou d'un souvenir, les personnages interrompent la narration, la commentent. Ou bien, comme pour reprendre leur souffle ou s'accrocher à ce qu'il leur reste de Mirad, ils lisent son journal intime et les lettres qu'il leur a adressées. Dans la mémoire de Djuka, surgissent aussi les scènes de tortures ou d'humiliation qu'il a subies dans un camp de prisonniers et dans un lieu de transit pour réfugiés.

Le récit bouscule la chronologie, lance le spectateur déconcerté sur une piste vite abandonnée, part ailleurs, revient, "Où étions-nous? ». Ce subtil agencement nous fait pénétrer par touches successives, sans effraction, dans la mémoire meurtrie des deux personnages. Nous les suivons de Foca à Rennes, de Sarajevo au camp serbe, de Karlovac à Saint-Nazaire...

Cette pérégrination d'un lieu de souffrance à un autre, cette souffrance encore présente, les comédiens, Claude Monnoyeur et Muriel Racine, la traduisent par une gestuelle minimale. Ils échangent quelques regards, tendent une main vers l'autre. Quand Fazila et Djuka se retrouvent après un cauchemar de 9 mois, le texte les suggère face à face, s'examinant pour se reconnaître tout à fait, constatant les ravages que l'autre a subis... René Loyon, contredisant la lettre du texte, a choisi de placer Djuka assis et derrière lui, Fazila debout, les mains posées sur les épaules de l'homme qu'elle avait cru mort. Le ton des comédiens reste neutre, distancié. Mais ce tâtonnement d'aveugles qui se cherchent est autant plus bouleversant. Dans le récit des massacres que l'auteur évoque avec une précision froide, les comédiens gardent le même ton presque «blanc », la même distance. « Nous marchons sans cesse sur un fil. » dit Claude Monnoyeur. Funambules sans filet, en maîtrisant leur émotion; ils permettent à la nôtre d'affleurer.

L'espace scénique est nu, presque vide, avec seulement deux chaises de bois, des chaises d'intérieur. Pourtant, ce lieu n'est pas une maison amie : personne n'a accueilli Djuka et Fazila. Nous ne sommes pas non plus chez eux puisqu'à la fin ils repartent «à la maison ", à Saint- Nazaire. Où sont-ils donc? Et puisqu'ils nous parlent, à nous, où sommes-nous? Aucun indice dans le texte ou la scénographie ne viendra nous éclairer. Dans ce lieu imprécis, comme hors du monde, ce face à face - ce coeur à coeur - va venir à bout de cette "paroi de verre » qui, disent-ils, se dresse entre eux et nous. Cette découverte mutuelle, cette (re)connaissance fait de Mirad, un garçon de Bosnie un beau moment de théâtre, généreux et libérateur. 


\section{NOTES}

1. Le TUFC l'a accueillie le 14 décembre à la Faculté des Lettres 